\title{
United States - Countervailing Measures Concerning Certain Products from the European Communities (WTO Doc. WT/DS212/AB/R): Recurring Misunderstanding of Non-Recurring Subsidies*
}

\author{
BY \\ GENE M. GROSSMAN \\ Princeton University \\ AND \\ PETROS C. MAVROIDIS \\ University of Neuchâtel and Columbia University
}

\section{Facts of the Case}

In United States - Countervailing Measures Concerning Certain Products from the European Communities (WTO Doc. WT/DS212/QB/R, henceforth Certain Products), the Appellate Body (AB) of the World Trade Organization was called upon to revisit the issue of whether the United States can legally impose countervailing duties following the privatization of state-owned enterprises that had received non-recurring subsidies. In twelve cases, the United States Department of Commerce (USDOC) had applied either the "gamma method" or the "same-person method" in assessing the impact of a change of ownership on the continued existence of a benefit from a countervailable subsidy. The European Communities challenged the legality of these methods.

Under the gamma method, the USDOC applied an "irrebuttable presumption" that the benefits from a non-recurring subsidy remain in existence for the entire useful life of the assets purchased with benefit of

\footnotetext{
* We are grateful to Henrik Horn, Doug Irwin, Arun Venkataraman and Jasper-Martijn Wauters for helpful discussions on the issue treated in this report.
} 
a subsidy. The USDOC did not undertake any inquiry into whether and to what extent a non-recurring subsidy continued to benefit the producers during the useful life of the assets. Rather, when confronted with a change of ownership, the USDOC simply allocated the subsidy benefit between seller and purchaser to match the fraction of the assets that had been transferred.

Following the AB ruling in United States - Imposition of Countervailing Duties on Certain Hot-Rolled Lead and Bismuth Carbon Steel Products Originating in the United Kingdom, (WTO Doc. WT/DS138/AB/R, henceforth Lead and Bismuth) that the gamma method is inconsistent with US obligations under the Agreement on Subsidies and Countervailing Measures (the SCM Agreement), the United States introduced the new, same-person method. Under this method, the USDOC conducts a twostep test to assess the continued existence of a benefit from prior subsidization. First, the agency decides whether the post-privatization entity is the "same legal person" as that which received the subsidy prior to privatization. To render this assessment, the USDOC considers whether there has been a continuity of general business operations, a continuity of production facilities, a continuity of assets and liabilities, and a retention of personnel. If, based on these criteria, the USDOC concludes that the privatization created no new legal person, it automatically concludes that the benefit from the subsidy still exists irrespective of the price paid by the new private owners for the assets of the state-owned enterprise. If the privatization has created a new legal person, then the benefits of the original subsidy are considered to have been extinguished.

The USDOC applied the gamma method in 11 of the 12 cases at issue in Certain Products. Of these, six were original investigations, one was an administrative review, and four were sunset reviews. The USDOC applied the same-person method in one case, which was an administrative review.

\section{Panel Ruling}

The European Communities argued before the WTO Panel that both the gamma method and the same-person method violate US commitments under the SCM Agreement to apply countervailing measures only when the removal of such measures would likely lead to continuation or recurrence of subsidization that causes or threatens to cause injury to domestic interests. Under Article 1.1 of the SCM Agreement, a subsidy can be deemed to exist only if a financial contribution by a government confers a "benefit" on the recipient. The European Communities argued, as it had 
done previously, that a firm cannot benefit when it purchases assets at arm's length and for fair-market value. Thus, according to the European Communities, a privatization of state-owned assets and for fair-market value creates an irrebuttable presumption that a subsidy no longer exists and so renders any countervailing measure imposed by another Member country illegal.

The United States conceded in the case before the Panel that it had acted in a manner inconsistent with its WTO obligations in seven of the twelve determinations; namely, those that involved application of the gamma method in original investigations or administrative review. In these cases, the United States acknowledged, the USDOC should have examined the continued existence of a benefit from the non-recurring subsidy. The United States denied having taken any actions inconsistent with its commitments in the four cases that involved sunset reviews, claiming that where no administrative review has taken place, its investigatory authority is under no obligation to consider any evidence when deciding whether the expiry of a countervailing duty would likely lead to a continuation or recurrence of subsidization causing injury. Finally, the United States argued that the same-person method addresses the objections raised by the $\mathrm{AB}$ in its rulings on the gamma method. Using the same-person method, the United States argued, the USDOC had considered whether a benefit from a subsidy continued to exist, as required by Article 21 of the SCM Agreement.

The Panel ruled in favor of the European Communities on both accounts. Concerning the four sunset reviews in which the USDOC had applied the gamma method, the Panel ruled that the United States was indeed obliged in such cases to examine the continued existence of a benefit. Without doing so, the USDOC could not have properly considered whether there would likely be continuing or recurring subsidization that would cause or threaten to cause injury absent the countervailing duty.

The Panel further judged the same-person method to be inconsistent with the SCM Agreement. The Panel in fact concluded that privatization at arm's length and for fair-market value will always necessarily extinguish the remaining portion of any benefit from a prior non-recurring subsidy paid to a previously existing state-owned enterprise. The Panel's central finding is put quite clearly in para. $8.1 \mathrm{~d}$ of its report, which states in part:

[o]nce an importing member has determined that a privatization has taken place at arm's-length and for fair market value, it must reach the conclusion 
that no benefit resulting from the prior financial contribution (or subsidization) continues to accrue to the privatized producer.

\section{US Appeal and AB Ruling}

The United States argued on appeal that the Panel had erred by failing to distinguish between a firm and its shareholders. According to the United States, a benefit received by a legal person cannot be redeemed by its shareholders. Thus, if a state-owned enterprise (a legal person) benefits from a financial contribution and if that same legal person continues to exist following privatization, then the benefit also continues to exist until it has been fully amortized or repaid. Privatization at whatever price even if at arm's length and for fair-market value - cannot eliminate the benefit of a prior contribution as long as the same legal person continues to exist. By this argument, the fact that private owners pay a fair-market price indicates only that these individuals have not received a windfall gain, but not that the legal person producing the subject merchandise is not still benefiting from the original subsidy.

The United States also appealed the Panel finding that its investigating authority is obliged to consider whether there is continuing benefit from a financial contribution whenever it conducts a sunset review, but it failed to advance supporting arguments on this point.

On the critical issue of whether a privatization at fair-market value might or must extinguish the benefit from a non-recurring subsidy, the $\mathrm{AB}$ accepted neither the claims advanced by the United States of the total irrelevance of the price at which assets are transferred, nor the ruling by the Panel that a sale at a fair-market price creates an irrebuttable presumption that the subsidy has been eliminated. In so doing, the $\mathrm{AB}$ reversed the position it had taken in Lead and Bismuth that privatization at fair-market prices inevitably extinguishes the benefit from a prior government contribution.

In its report, the $\mathrm{AB}$ drew upon its interpretation of the word "benefit" in Canada-Measures Affecting the Export of Civilian Aircraft (WTO Doc. $\mathrm{WT} / \mathrm{DS} 70 / \mathrm{AB} / \mathrm{R})$. There it had ruled that the word implies some kind of comparison, and that "the marketplace provides an appropriate basis for comparison... because the trade-distorting potential of a 'financial contribution' can be identified by determining whether the recipient has received a 'financial contribution' on terms more favorable than those available to the recipient on the market" (Certain Products, para. 157). 
Whereas the United States had argued that the utility value of the assets acquired with the benefit of the government's financial contribution had not been eliminated as a result of the transfer of these assets to new private owners, the $\mathrm{AB}$ saw the utility value as irrelevant for the legal purpose of assessing the continued existence of a "benefit". Rather, the AB insisted that the marketplace should be used as the starting point for any such assessment.

The $\mathrm{AB}$ rejected entirely the United States' argument to the effect that the price at which assets are acquired is irrelevant to a firm's use of these assets, and the other decisions it makes subsequent to that acquisition in regard to the prices and quantities of its production. On this point, the $A B$ wrote in Certain Products, para. 103, that

[w]e fail to see the basis for the assumption by the United States that, regardless of the sale price of the firm, its costs and volume of production will remain the same, since these costs include, as a necessary component, the cost of capital. Indeed, the Panel noted that private investors are "profit-maximizers", who will seek to "recoup[] through the privatized company ... a market return on the full amount of their investment." For example, if a government makes a "financial contribution" that "benefit [s]" a state-owned enterprise, and then sells that enterprise for less than its fair market price, would this not normally result in a "better off" return for the private capital newly invested in that enterprise? Would that not suggest, as a consequence, that the under-priced enterprise may then attract more investment than it would have attracted otherwise, if the government had sold it for fair market price? Why would this government-induced additional investment not then reduce the enterprise's cost of raising capital (either by borrowing it from the bank or from, say, shareholders) and, ultimately, reduce the firm's overall costs of production?

However, the AB disagreed with the Panel's judgment that a benefit from a prior financial contribution to a state-owned enterprise can never continue to exist following the privatization of the enterprise's assets at arm's length and for fair-market value. To reach this conclusion, the $\mathrm{AB}$ drew a distinction between the exchange value of goods and services and their scarcity value. It noted that, "[u]nder certain conditions (e.g., unfettered interplay of supply and demand, broad-based access to information on equal terms, decentralization of economic power, an effective legal system guaranteeing the existence terms of private property and the enforcement of contracts), prices will reflect the relative scarcity of goods and services in the market" (Certain Products, para. 122). Under these conditions, the $\mathrm{AB}$ opined, the "actual exchange value of 
the continuing benefit of past non-recurring financial contributions bestowed on the state-owned enterprise will be fairly reflected in the market price."

But the $\mathrm{AB}$ noted that it could imagine circumstances in which the market price of the assets would not reflect "the exchange value of the continuing benefit." Such circumstances might arise, for example, if the government were intervening in the market to induce certain outcomes that it deemed socially or politically desirable. Then, in the view of the $\mathrm{AB}$, the value of the assets might be altered by the government policies or by the conditions in which the private owners would subsequently be allowed to make use of the assets. When the fair-market value diverges from the "actual exchange value of the continuing benefit," an investigatory authority could legitimately find that a benefit of past non-recurring financial contributions to a state-owned enterprise continues to exist beyond the time of an arm's-length privatization. The $\mathrm{AB}$ gave no concrete example of the sort of situation it had in mind.

In sum, the AB affirmed the Panel's ruling that the United States had acted inconsistently with its obligations under the SCM Agreement in the twelve specific determinations at issue in Certain Products. In so doing, it ruled that the same standards ought to apply for showing continuing existence of benefits from financial contributions in sunset reviews as in original investigations or administrative reviews. However, the $A B$ overturned the Panel's finding that privatization at arm's length and for fair-market value presumptively extinguishes any benefit from a nonrecurring financial contribution bestowed upon a state-owned enterprise. Rather, it ruled that whereas such a privatization creates a rebuttable presumption that a benefit ceases to exist, there may be circumstances in which an investigatory authority can find otherwise.

\section{Discussion of the AB Ruling}

In our report last year on Lead and Bismuth, we concluded in relevant part that ${ }^{1}$

The $\mathrm{AB}$ ruled incorrectly that a change in ownership of assets at fair market value provides per se evidence of an absence of subsidy, because it precludes 'benefit' to the acquiring firm. A consistent interpretation of the SCM

${ }^{1}$ See Gene M. Grossman and Petros C. Mavroidis, "Here Today, Gone Tomorrow? Privatization and the Injury Caused by Non-Recurring Subsidies," in Grossman and Mavroidis (2003). 
Agreement calls for a 'but for' test for continuing injury from a non-recurring subsidy. The authorities in the importing country should periodically review whether its domestic producers of like products are suffering harm relative to what would be their economic condition but for the prior nonrecurring subsidy. To effect this test, the authorities must ask whether or not the subsidized investments have become infra-marginal in the light of subsequent events in the industry

(p. 34).

In Certain Products, the $\mathrm{AB}$ has reversed its position that a change in ownership at fair-market prices provides per se evidence of the absence of subsidy. We concur on this issue. However, we find fault with the reasoning used by the $\mathrm{AB}$ in reaching this conclusion. And we disagree with its finding that a change in ownership at fair-market prices provides a rebuttable presumption that a subsidy no longer exists.

By insisting that the sales price at which a privatization takes place is relevant to the determination of the continued existence of benefit from a subsidy, the $\mathrm{AB}$ has failed to understand the economic concept of a sunk cost. The United States is correct when it argues that the price at which a profit-maximizing enterprise acquires an asset will not affect its subsequent production and pricing decisions. The fact that such an enterprise will wish to "recoup a market return on its investment" is simply irrelevant to its subsequent business decisions. Consider, for example, an art dealer who misjudges the public appeal of a painting and pays $€ 1000$ for an acquisition. Such a dealer may well wish to recoup a market return on his investment, but if the amount collectors are willing to pay for the painting is only $€ 500$, the dealer would be well advised to sell at that price. Now compare this dealer to another who has been lucky enough to acquire a similar painting for $€ 100$. If this second dealer is a profit maximizer, he will not sell the painting for $€ 120$ and be satisfied with a fair-market return on his investment. Instead, he will hold out for the full $€ 500$ that collectors are willing to pay. In short, the dealer who acquires an asset for $€ 1000$ and another who acquires one for $€ 100$ - if they are both profit maximizers - will indeed follow similar pricing strategies. Once the dealers have purchased the paintings, the amounts they paid become sunk costs; they have no bearing on subsequent, profitmaximizing behavior.

Similarly, a firm that acquires assets in a privatization of a state-owned enterprise will maximize profits by producing up to the point where the marginal revenue from the last unit of output is just equal to the marginal cost. Inasmuch as the marginal cost of production is not affected by the 
price paid for machinery and equipment, the profit-maximizing behavior will not be affected by such bygone considerations.

The logical difficulties that stem from the $\mathrm{AB}$ interpretation of the word "benefit" in Art. 1.1 of the SCM Agreement in terms of the market value of the privatized assets can be seen in a comparison of two hypothetical occurrences. Imagine a machine that can be used to create $€ 50,000$ in present discounted profits. A private, profit-maximizing firm would be willing to pay up to $€ 50,000$ to acquire such a machine. Let the production cost of the machine be $€ 100,000$. Then no firm will be willing to buy the machine absent any government inducement. Now consider Event 1, in which the government offers a subsidy of $€ 50,000$ to any firm willing to buy and install the machine. Such a subsidy is sufficient to induce one or more private firms to make the purchase. In the event, and if the machine is used in a way that causes injury to firms in importing countries, surely the SCM Agreement would recognize the existence of a subsidy and permit a countervailing duty.

But now consider Event 2, in which the government buys the machine itself in the name of a state-owned enterprise. On the next day, it offers to privatize the enterprise by selling the firm's assets to the highest bidder. The privatization - which occurs at arm's length - will take place at a fairmarket price of $€ 50,000$. But, in this case, the $A B$ would deny the existence of a subsidy, and deny Member countries the right to countervail. In both Events, the private firm that eventually makes use of the machine pays $€ 50,000$ for the acquisition. In both cases, the firm uses the machine to produce profits of $€ 50,000$ and, in the process, inflicts injury on firms in importing countries. In both cases, the government's net financial contribution is $€ 50,000$. Yet the $\mathrm{AB}$ construes a benefit from a financial contribution in one situation but not the other. It seems unlikely that this was the intention of those who drafted the SCM Agreement. ${ }^{2}$

The $\mathrm{AB}$ interpretation of "benefit" also creates logical difficulties for the treatment of non-recurring subsidies paid directly to private enterprises. ${ }^{3}$ The ownership shares of such enterprises turn over regularly in

${ }^{2}$ Of course, we cannot be sure that those who drafted the agreement did not intend to draw a distinction between these economically equivalent events. To assess their intentions, we must analyze the apparent objectives of the agreement in the light of its various provisions. We have conducted just such an analysis in Grossman and Mavroidis (2003), where we concluded that the only interpretation of the text that accords with the apparent objectives of the agreement is one that associates "benefit" with a gain in competitive advantage.

${ }^{3}$ We are grateful to David Palmeter for this observation. 
transactions on private equity markets. Such sales take place at arm's length and for fair-market value. And those who purchase the shares subsequent to the payment of the subsidy do not personally benefit from the original subsidy. Does the AB consider a part of the "benefit" to be extinguished with each such private equity sale?

As we argued in Grossman and Mavroidis (2003), the only interpretation of the term "benefit" in Article 1.1 of the SCM Agreement that is consistent with the aims and objectives of those who drafted the Agreement is one that attributes benefit whenever a firm's competitive position is advantaged relative to what it would have been but for the government's financial contribution. We view the main objective of the SCM Agreement as being to discourage subsidies that threaten harm to competing producers in importing countries. To achieve this objective, it makes no sense to interpret "benefit" in terms of the financial wealth of the owners of a firm. Rather, the potentially adverse effects of a subsidy on producers in an importing country can be avoided only if a subsidy is deemed to exist whenever a government's financial contribution impacts the competitive situation in an industry. And, as we have argued, the price at which a change in ownership takes place has no bearing on the subsequent competitive conditions.

In Grossman and Mavroidis (2003), we also found fault with the procedures used by the United States for assessing whether the removal of a countervailing measure would likely lead to a continuation or recurrence of subsidization causing injury. Our arguments there - which related to use of the gamma method - apply with equal force to the same person method that was subsequently developed by the USDOC. The US methods presume that the benefits from a non-recurring subsidy necessarily survive for the full average useful life of the assets, provided that the legal person that purchased the assets with benefit of the subsidy continues to exist. We do not agree. Events that occur subsequent to the payment of a subsidy may render inframarginal an investment that was formerly unprofitable. If an investment becomes inframarginal, it is impossible to argue that the subsidy is the cause of ongoing injury. In such circumstances, the injury would be present even if the subsidy had never been paid. We therefore conclude that the same person method does not fulfill the United States' obligation under Article 21.1 of the SCM Agreement to ensure that

a countervailing duty shall remain in force only as long as and to the extent necessary to counteract subsidization which is causing injury. 
To fulfill this obligation, the USDOC should conduct a review that addresses the hypothetical question of what industry conditions would have been but for the payment of the non-recurring subsidy.

We do concur with the $\mathrm{AB}$ ruling that the obligations imposed on an investigatory authority by the SCM Agreement apply with equal force to the reviews mandated by Article 21 of the Agreement. The Agreement defines a countervailable subsidy in terms of the cost to the government, the benefit to a recipient, and specificity to an enterprise or industry. Since the existence of a benefit forms part of the definition of a subsidy, and countervailing duties can be continued only if there is a subsidy that is causing injury (emphasis added), the obligation to identify a beneficiary applies not only to the original investigation, but also to subsequent review proceedings.

\section{Conclusions}

We believe that privatization at arm's length and for fair-market value does not presumptively extinguish the benefits from a non-recurring subsidy to a state-owned enterprise. Rather, an investigatory authority should periodically review whether the prior subsidy continues to affect competitive conditions in such a way as would cause or threaten injury to a domestic industry in an importing country in the absence of a countervailing duty. The investigatory authority should compare conditions in the industry to those that would have prevailed but for the subsidy payments.

As we noted in last year's report, there is no need to amend the SCM Agreement in order that it might be applied in an economically-friendly manner.

\section{References}

Grossman, Gene M. and Petros C. Mavroidis. 2003. Here Today, Gone Tomorrow? Privatization and the Injury Caused by Non-Recurring Subsidies. A Discussion of the Appellate Body Report on United States - Imposition of Countervailing Duties on Certain Hot-Rolled Lead and Bismuth Carbon Steel Products Originating in the United Kingdom in H. Horn and P. C. Mavroidis, eds., The WTO Case Law of 2001. Cambridge: Cambridge University Press. 